\title{
Transnational History and Colonial Records: Locating Bengali Mobility in the British Malaya
}

\author{
Gazi Mizanur Rahman \\ Ph.D. Candidate in History and International Studies, Faculty of Arts and Social Sciences, \\ Universiti Brunei Darussalam, Brunei Darussalam
}

DOI: https://doi.org/10.14710/jmsni.v3i2.6267

Abstract

By the late 1980s, some historians began to identify their works as transnational history - which dealt with the past human mobility, and the circulation of goods, information, and ideas across the globe. Colonial records are an essential source for reconstructing transnational history. However, some of the colonial census-makers were not aware of the racial identity of transmigrants during the population enumeration. They categorised the transmigrants under different umbrella heads, and due to their stringent systems of cataloguing, the identity of diverse migrants was misplaced or generalised in census reports. Therefore, these certain ambiguities complicate the reconstruction of the transnational history of some specific migrant

Received:

November 7, 2019

\section{Accepted:}

December 8, 2019

Corresponding Author:

rahmangazi@yahoo.com communities. With the impact of British colonialism in present-day South and Southeast Asia, South Asian multi-ethnic people, including Bengalis, migrated to Malaya. Initially, the British colonial administrators categorised the South Asian multi-racial migrants under different heads including "Bengalis \& c.", "Tamils \& c." and "Indians". These umbrella terms in colonial records create problems in reconstructing the transnational history of anyone specific race from South Asia, such as the Bengali. Through a reinterpretation of colonial documents, empirical evidence, and oral interviews, this paper attempts to locate the Bengali migrants in British Malaya.

Keywords: Bengali Migration; British Malaya; Colonial Records; Transnational History.

\section{Introduction}

Migration is a crucial aspect of transnational history which has taken place since the beginning of human civilisation- whether free or forced. It is at the "heart" of modern Asian history (Amrith 2011). With the arrival of European colonial powers in Bengal, it covers present-day Bangladesh and West Bengal of India. and Malaya, in particular, after the establishment of British authority in both regions, the pattern of the links and flows of human mobility was changed. In 1826, British East India Company founded Straits Settlements comprised Singapore, Malacca, and Penang and governed them from Calcutta (presently Kolkata) as one administrative unit until the $1850 \mathrm{~s}$. These administrative links combined with maritime highways, facilitated the mobility of South Asian people, including Bengali towards British Malaya (it covers mainly the area of present-day Singapore and Malaysia. British Malaya, Malaya, and Straits Settlements have been used interchangeably in this paper.

However, the identities of transnational migrants from different parts of South Asia were generally merged and described as "Bengalis \& c.", "Tamils \& c." and "Indians" in the colonial records. Such generalisations often hide the identity of specific migrating groups from South Asia. This has made it difficult to reconstruct the transnational history of some South Asian people, in particular, the Bengali. Nowadays, the area of Bengal is shared with two nation-states, Bangladesh and India; therefore, the term Bengali denotes the Bangla-speaking people.

The existing literature on Bengali migration in the Malay Peninsula, focus on the current state of migration from an economic and sociological perspective. These are a concern on a wide range of issues, for instance, Bengali skilled and unskilled labour migration, policies, migrant family's economy and remittance management, migrant entrepreneurship, migrant rights, migrants' gender, health, and social developments (Rahman 2017; Ullah 2010; Ullah 2007; Sultana 2008). Some narratives explore 
the micro-histories of the Bengali migrants in Malaya without serious historical insight (Sengupta 2013; Khondker 2008, 178-198). Therefore, the existing literature are mostly discussing the current migrations as well as micro-histories of the Bengali migrants, which have not addressed the general problem of misplaced Bengali identity in the colonial records.

Moreover, contemporary literature on the transregional migrations of the diverse population from South Asia to Southeast Asia have been discussed under the umbrella of "Indian". For instance, a rich literature has been explored the voluntarily and involuntarily "Indian" migrants who dispersed between the $19^{\text {th }}$ and $20^{\text {th }}$ centuries and formed a diasporic community in Southeast Asia. Some scholars have illustrated the socio-economic conditions of the "Indian" diasporic community during the colonial and post-colonial era (Tinker 1974; Belle 2015; Chanderbali 2008; Sandhu 1961; Arasaratnam 1970). As a specific migrating group of the "Indian", the Bengalis are hidden and unclear among those scholarships. This article studies two inter-related issues for relocating the Bengali migrants. First, it deals with the transnational history and ambiguities in colonial documentation; and examines the confusion about the term "Bengali" which was bundled together under the generic term of "Indian," "Hindustani," or "Punjabi". Secondly, this study addresses multiple ways to relocate the Bengali mobility in British Malaya.

\section{Method}

This study applies the historical method and relies on a range of primary and secondary sources. Materials have been collected from different libraries and archives located in Singapore, Malaysia, and Bangladesh. Moreover, the researcher interviewed some of the Bengali descendants in Singapore. This paper suggests that the Bengali mobility in the public space of the Malay Peninsula in the postcolonial times was built on their mobility in the colonial period, which deserves critical appreciation.

\section{Transnational History and Colonial Documentation}

In 1916, Randolph S. Bourne introduced the term "transnationalism"; it denotes the process of adopting sustain multidimensional social relations by the transmigrants together with their origin home and host societies (Basch, Schiller, Blanc 2005, 8). Recently, scholars from different fields, including migration studies, are using the term very extensively. Historians define the term in historical perspective. With the turn of the $21^{\text {st }}$ century, a global approach has become influential to historical writings, along with a stress on transnational actors and themes, including races, nongovernment organisations, and migrations (Iriye 2013, 1, 11). Some historians began to identify their work as transnational history, which is a study of the past through the lens of contemporary experiences such as global connectivity, mobility of the people, and the circulation of goods, information, and ideas (Bayly et al. 2006, 1443). Sven Beckert and Patricia Seed suggest that transnational history reconstructs the aspects of the human past, mobility of objects and ideas that transcend any one modern state, empire, or other politically defined boundaries (Bayly et al. 2006, 1443, 1445). Transnational history deals with the links and flows of the people, ideas, and products, "that operate over, across, through, beyond, above, under, or in-between polities and societies" (Iriye and Saunie 2009, xviii).

Some scholars including Akira Iriye and Emmanuel Akyeampong have already worked on the transnational history and space-making of transnational communities. Akyeampong has revealed the flows of involuntary and voluntary migrants at the global level between the $16^{\text {th }}$ and the $19^{\text {th }}$ century (Akyeampong 2013, 163-171). From the transregional vantage point, the flows of South Asian people, objects, cultures, and ideas were shown within the Indian subcontinent as well as the transcontinental connectivity between the mid- $18^{\text {th }}$ century and the mid-20 $0^{\text {th }}$ century (Markovits, Pouchepadass, and Subrahmanyam 2003).

Transnational historians also explore transoceanic connectivity, mobility of a specific group of people, and their space-making in distant places. Nikkeijin (Japanese) arrived on Brazilian shores around 1908 and formed a transnational community in Brazil. Japanese Peruvians (Peruvian citizen 
but their forefather migrated from Okinawa to Peru between 1879 and 1923) developed their ethnic identity and created a transnational space in Peru (Knight 2002, 16, 20). A Persian transnational community within the Arab Gulf and their space-making in Bahrain city from the 1860s to the 1930s has been historicised by Nelida Fuccaro $(2005,39-58)$. The transnational history of the French people shows their intermingling with other communities and "Frenchness" in Australia from the late $19^{\text {th }}$ to the early $20^{\text {th }}$ centuries (Bergantz 2015). The Hadrami diaspora in Arab, India, and Southeast Asia has been explored through the lens of transnational history, religion, and culture (Ho 2006). James Onley has worked at the micro-level of transnational history. He has examined two transnational families - the Safar and Kanoo family - who originated from Bahrain but extended their connections from the Arab Gulf to the UK and the USA during the $19^{\text {th }}$ and the $20^{\text {th }}$ centuries (Onley 2005; Onley 2007). Thus, transnational historians have shown the exemplary works from the transnational world to transnational family, as well as space-making in distant places.

However, it might be problematic to reconstruct the transnational history of a specific migrant group because of the misplacement of their identity in colonial documentation. Colonial enumerators misplaced the identity of some transmigrants in the records, in particular, the population census reports. Benedict Anderson has shown how the "aboriginal Eden" was misplaced in colonial records in the Philippines. He has further demonstrated how "Cochin-Chinese" was mapped in the colonial demographic topography in Indonesia (Anderson 2006, 166, 168-69). South Asians were categorised under the head of "prohibited immigrant", "aliens", "natives of Asia", and "asiatics" in Australia during the colonial period (Allen 2005, 111-124). Therefore, Anderson suggests that these umbrella terms were the "mentalités of the British colonial census-makers", and "not in the construction of ethnic-racial classifications, but rather in their systematic quantification" (Anderson 2006, 164, 168).

In the context of British Malaya, with the expansion of British imperialism and capitalism, a diverse population from South Asia migrated to Malaya because it offered new and expansive work opportunities in the plantations and mines, which created job opportunities. Majority of South Asian labourers came from South India, but a large number of migrants came from northern India and Bengal. Besides, there was huge demand for skilled human resources in British Malaya, in particular, clerks, physicians, engineers, and medical practitioners during the colonial period. Most of the Bengalis were engaged as doctors, lawyers, clerks, shipping management, engineers and maritime labourers in the $19^{\text {th }}$ and mid-20 $0^{\text {th }}$ centuries. This mobility facilitated the formation of Bengali transnational community in the Malay Peninsula over time. However, the British colonial records refer to migrants from different parts of South Asia by the generic term "Indian", "native of India", "eastern Indian", and to some extent "aliens", and "others". Risley and Gait informed that the people of British India were enumerated under the heading of "Indian" in the census (Risley and Gait 1903, 91). The Registrar General of Statistics categorised the population as "Indian" in the Straits Settlements, Federated Malay States, and Unfederated Malay States (Aiyar 1938, 116). It was problematic to attribute the term "Indian" or "native of India" to all South Asian migrants to Malaya because the people from India were different by region, religion, culture and languages. The Bengalis were also known as "East Indians". For instance, in 1859, the whole population of the Prince of Wales Island (Penang and Province Wellesley) was segregated into Europeans and descendants, East Indians, Malays, Chinese, and Indian proper (Straits Times, hereinafter, ST, 2 July 1859). Davis suggested that there was no sure way to figure out the exact number of "East Indians" migrants from India (Davis 1951, 101).

The Bengali were also categorised under a few headings like "Bengali and other natives of India", "Other Natives of India", and "Tamils and Other Natives of India in the reports of Straits Settlements during the $19^{\text {th }}$ century. The British census takers used these terms for categorising the South Asian migrants. By analysing the censuses of the Straits Settlements, Federated Malay States, and Malaysia from 1871 to 1980 , Charles Hirshman arranged all ethnic classifications into a table (Hirschman 1986, 552-82; Rashid 2012, 67). Initially, the Bengalis were enumerated under the head of "Bengalis \& other Natives of India", however, the system of enumeration was changed to the "Tamils and other Natives of India" in 1891, because of increasing the number of Tamil labourers proportionate to other Indian races. 
Locating the Bengali migrants is also problematic because on many occasions, the non-Bengali people from different parts of India, in particular, Punjabis and Sikhs, introduced themselves as "Bengali" (Braddell 1934, 44; Hirschman 1986, 564; McCann 2011, 1477). This was because, as Metcalf argues, the people of northern India used to come to the Malay port cities via Calcutta (Metcalf 2007, 52, 111). The north Indians identified themselves as "Bengali" to non-Indian enumerators simply because they commonly understood this term (Sandhu 1961, 21).

The above discussions show that the diverse South Asian migrants were enumerated under some umbrella terms, including "Indians". In terms of the postcolonial paradigm, the term "Indian" denotes the inhabitants of the Republic of India. However, this article is more concerned about the colonial era. During the colonial period, the officials of the India Office in London used the term "Indian" to denote the diverse people of South Asia region because most of the territory of that region was under the jurisdiction of British India. Hence, the inhabitants under British India were mostly categorised under the simple term "Indians" (Metcalf 2007, xii). British India (a larger part of presentday South Asia) was constituted of a diverse race, language, and culture. Dipesh Chakrabarty has problematised the idea of "Indians" and suggested that the British represented the diversity of "Indian" pasts for about two hundred years through a homogenising narrative. However, he deconstructed the idea of "Indian" through a transnational enterprise (Chakrabarty 1992, 1-5; Chakrabarty 2000, 27). It is relevant to add here that Arjun Appadurai vividly has pointed out the cultural homogenisation of the nation-states during the postcolonial period. He suggested that it is the core problem that today's global interactions are the tension between cultural homogenisation and cultural hetero-genisation. According to Arjun Appadurai, "Indianisation" is one example of cultural homogenisations (Appadurai 1990, 295).

However, the abovementioned categorical designations in colonial documentation not only hinder the reconstruction of transnational communities' histories but also create difficulties for interracial discourses. Recently some scholars have addressed specific identities in their works instead of introducing them as "Indian". For instance, Sunil Amrith's work convincingly demonstrated how the missing identity of the Tamils among the Indian migrants could be recovered (Amrith 2013). Arunajeet Kaur (2009), Gerard McCann (2011), and Isabella Jackson (2012) clearly illustrate the history of the Sikh community in British Malaya. By doing so, this article attempts to locate Bengali mobility in Malaya.

\section{Multiple approaches to deal with the ambiguties}

Despite the foregoing ambiguities in the colonial records, through critical interpretations of the sources, it is still possible to argue that the Bengalis were supposed to be relatively better placed to migrate in British Malaya.

\section{Census Readings}

The most official figures covered only British Indian ports of Bombay (presently Mumbai), Madras (presently Chennai), Karachi and Calcutta, but it did not mean that all migrants sailed from those respective ports to Malaya (Davis 1951, 98). They could migrate through overland as well as disembark from other unregulated ports. Evidence shows that the Indian people, including Bengalis, crossed borders from Burma (Myanmar), and disembarked from the Rangoon port. Some Bengalis, including Dr Krishna Chandra Sinha, Dr Amiya Bag, and Hena Sinha migrated from Rangoon port to Malaya (Sengupta 2013). The most extensive inter-provincial mobility of Bengal people was towards Myanmar chiefly to Arakan State. Most of them returned home, but many were permanently settled on the wasteland grants in Upper Burma (Risley and Gait 1903, 90-91, 131, 136; Kaur 2011, 137; Lwin 2008, 492). Some of the Bengali people in Burma migrated further east to the Malay Peninsula by using Thailand as a corridor or overland via Burma-Malaysia border. Thailand is a regional corridor till date for illegal migration and trafficked people from all neighbouring countries (Ullah 2007). 
The statistics of birthplace might be an indirect mode of estimation of Bengali migrants. During the late $19^{\text {th }}$ and the early $20^{\text {th }}$ centuries, different census reports (Table 1) mentioned that the birthplace of the Bengalis was in "Adjacent Countries", "Asiatic Countries", "Asian Countries", and "Outside India." Adjacent Countries includes the Straits Settlements, Malaya, and present South Asian states (Census of the British Empire 1901 1906, 106). Asiatic Countries meant many Asian nations including Borneo, China, Hong Kong, Java, Sumatra, Philippines, and Japan (Census of British Empire 1901, 106-7). Asian Country was demarcated as Straits Settlements and Malay, Hong Kong, Siam, Afghanistan, Arabia, Armenia, Asia Minor, Bhutan, Ceylon, China, Japan, Maldives, Nepal (Gait 1913, 134); Outside India denotes Asian and European countries, including farther India, which covers present Southeast Asia, including Myanmar, Malaya, Thailand, and Indo-China (Risley and Gait 1903, 106; Clifford 1904). Though these combined terms were attributed to the quantification of Bengalis birthplaces in Southeast Asian countries, it shed light upon a significant number of Bengalis who born in British Malaya.

Table 1. The number of Bengalis as per Birthplace

\begin{tabular}{|c|c|c|c|c|}
\hline \multirow{2}{*}{$\begin{array}{l}\text { Year of the } \\
\text { Reports }\end{array}$} & \multicolumn{4}{|c|}{ Birthplaces of the Bengali } \\
\hline & Outside India & $\begin{array}{l}\text { Adjacent } \\
\text { Countries }\end{array}$ & $\begin{array}{l}\text { Asiatic } \\
\text { Countries }\end{array}$ & Asian Countries \\
\hline 1891 & 194,155 & Not available & & \\
\hline 1901 & 186,468 & 169,081 & 3,228 & Not available \\
\hline 1911 & Not available & & & 117,374 \\
\hline
\end{tabular}

Source: Risley and Gait 1903, 134.

As per the enumeration of 1911, the total number of population was 463,05,642 in Bengal and its adjacent states (Gait 1913, 122-4). Most of them were born in India; however, about 117,374 individuals of Bengal were born in "Asian Countries" which included the Straits Settlement (Gait 1913, 127-128, 134). Therefore, it is well assumed that the Bengalis who were born in Straits Settlements, their parents had migrated many years back across the Malaya.

Likewise the Bengal Government, the census report of the Straits Settlements also reported that some Bengalis were born in Bengal but enumerated in the British Malaya. For instance, Figure 1, 2, and 3 show those Indians whose birthplace had in different places including Bengal, Madras, and Central Province but enumerated in Singapore, Malacca, and Penang.

\section{Birthplace of Indians who were enumerated in Singapore in 1911}

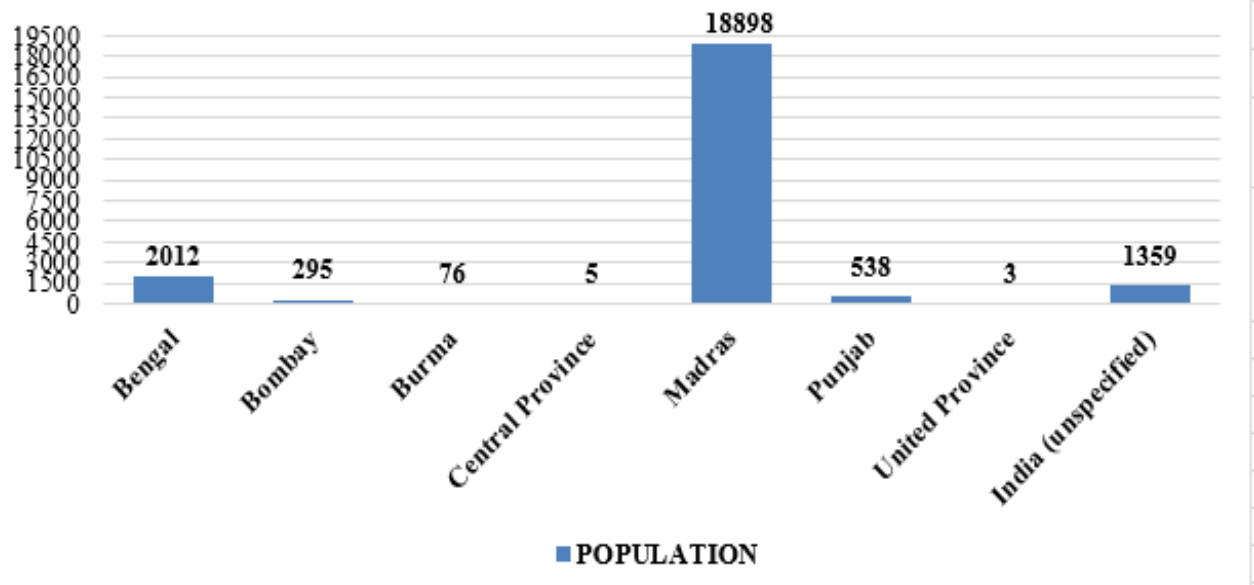

Figure 1: Birthplace of Indians who were enumerated in Singapore, 1911 Source: Marriott 1911, 72-75. 


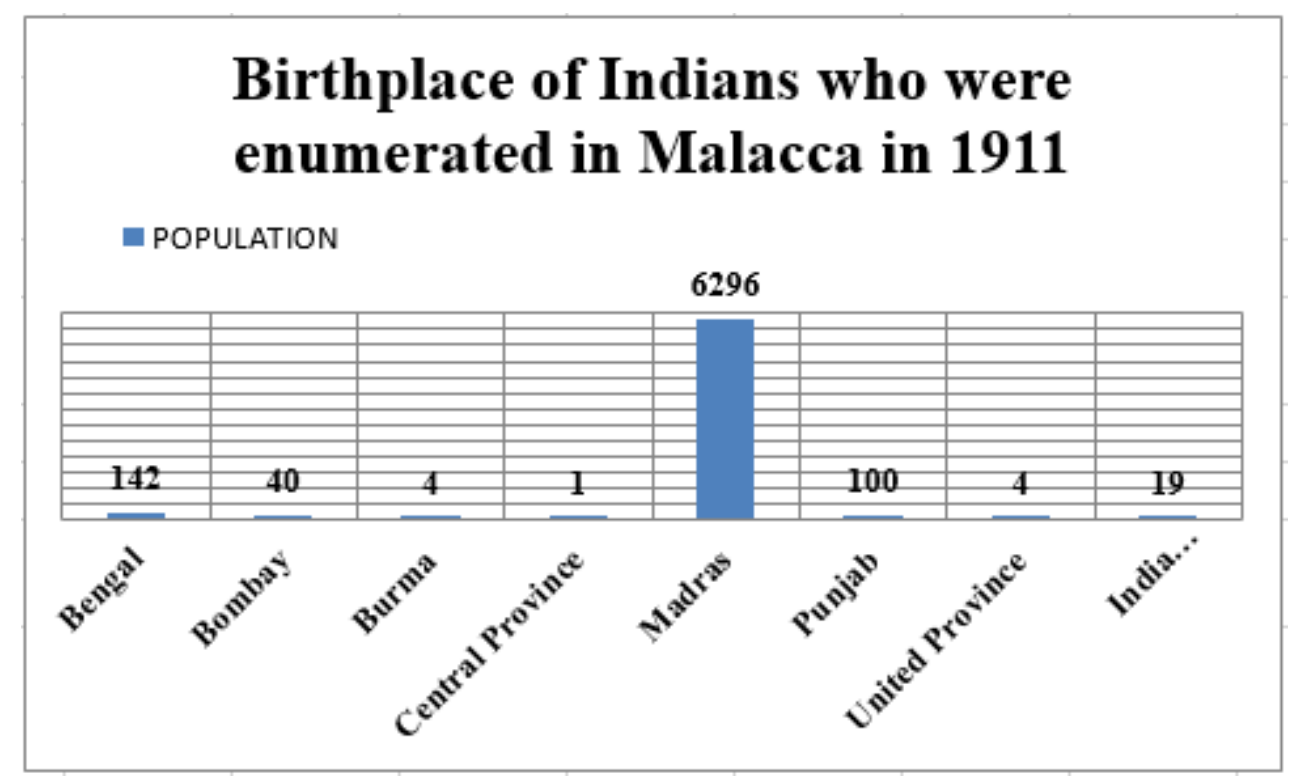

Figure 2. Birthplace of Indians who were enumerated in Malacca, 1911 Source: Marriott 1911, 72-75.

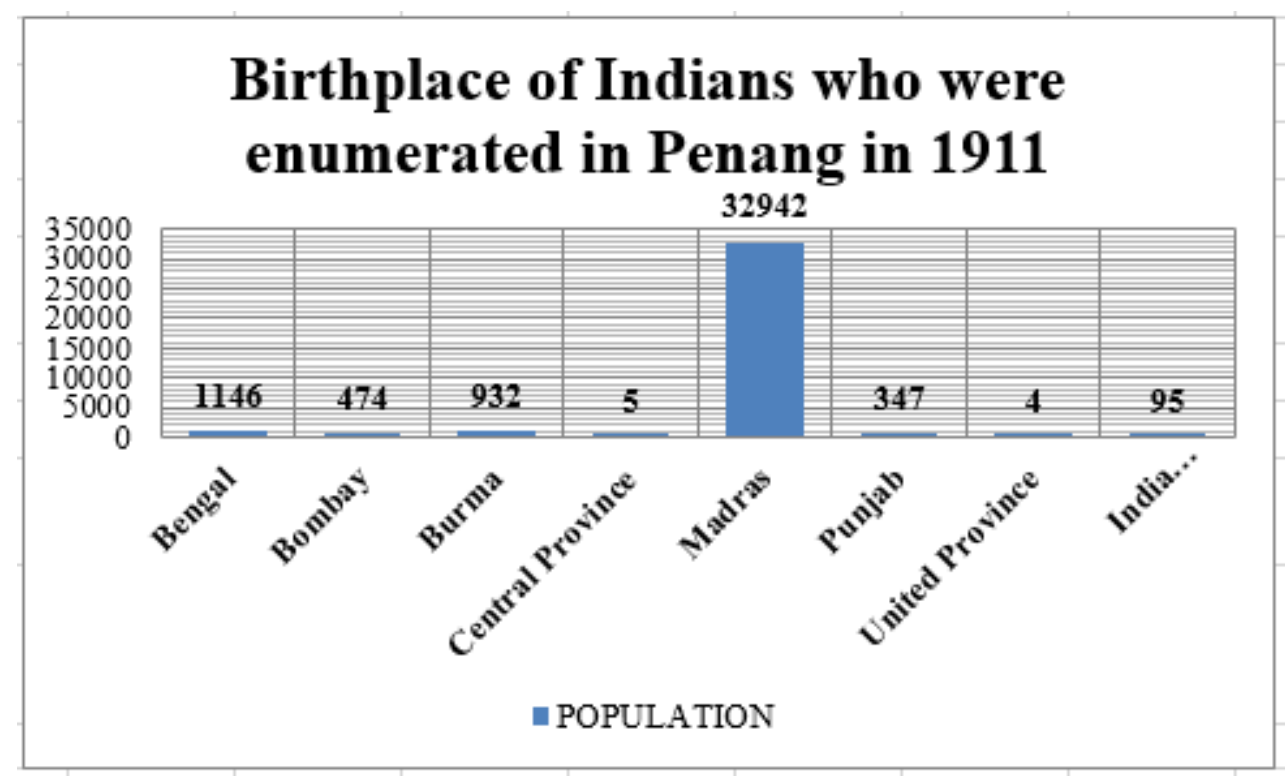

Figure 3. Birthplace of Indians who were enumerated in Penang, 1911 Source: Marriott 1911, 72-75.

Some colonial records mentioned the Bengali population without references to any specific number in Straits Settlements. Therefore, though there have certain ambiguities, it reflects on the existence of Bengali mobility. For instance, a report of 1810 informed that the number of Chulias and Bengalis were 5,604 in George Town (Nasution 2014, 49, 56). In 1872, Charles Irving, the Straits AuditorGeneral, found a busy wood and attap (traditional housing found in the kampongs of Brunei, Indonesia, Malaysia and Singapore) township of about 3,000 people of many races including Bengalis (Sadka 1968, 28). In 1844, almost 50,000 inhabitants, including Bengali, were in the Province of Wellesley (Singapore Free Press and Mercantile Advertiser, hereinafter, SFPMA, 25 April 1844).

Apart from the colonial records, some scholars have reaffirmed the existence of Bengalis in miscellaneous ways. C. M. Turnbull pointed out that the majority of Indians were South Indians, but that there were also Sikhs, Punjabis, Gujaratis, Bengalis, and few Parsis by 1860 (Turnbull 1989, 37; Pirbhai 2003). Some Indians came from Punjab, United Provinces, Bombay, and Bengal in Malaya in 1931 (Aiyar1938, 115). Nasution suggests that north Indians who came to Penang before the Second World War were mostly Bengalis, Gujaratis, Parsis, Biharis, 'U.P.- Wallas' (from Uttar 
Pradesh), Pathans and Punjabis (Nasution 2014, 6). Rajeswary Ampalavanar also echoed the same that except the predominant Tamil, there were principally Punjabis, Bengalis, Gujaratis, and Sindhis in Singapore and Malaya (Ampalavanar 1981, 1). Kernial Sing Sandhu suggested more profoundly that Indian Punjabi and Bengali counterparts are identical with their professions (Sandhu 1961). Hence, the reaffirmations of some scholars demonstrate that a significant number of Bengali among other South Asians migrated to Malaya.

A technical shortcoming of the census was that some Bengalis introduced themselves as Malay, and the offspring of Bengali-Malay parentage or Jawi Perkan were not enumerated as "Bengali" in the censuses. Jawi Perkan was the Indians and Chinese married local Malay women in British Malaya. Their offspring were called as Jawi Pekan or Jawi Peranakan. In 1858, J. D. Vaughan confirmed that Jawi Pekan was termed to the children of Malay mothers and Kling or Bengali fathers (Nasution 2014, 8, 121, 125; Turnbull 1989, 67). Habibul Haque Khondker suggested that many of Banglaspeaking migrants mostly Muslims who hailed from East Bengal (now Bangladesh) identified themselves as Malay as well as some learned local language, and assumed Malay identity through interracial marriage (Khondker 2008, 183-85).

Some Bengali migrants were indifferent to the question of ethnic identity. For instance, the Bengalis who came from East Bengal to Malaya in the early 1920s their offspring were registered as Pakistani in the 1950s because then Bengal was known as East Pakistan. They still maintained "Pakistani" as racial identity on identification card even after separation from Pakistan in 1971. $\mathrm{Mr}$ Anawarul Haque's father migrated from Sylhet to British Malaya, but still "Pakistani" is written on his identification card (Interview with Anwarul Haque on 25 July 2018). Some Bengalis opted for Malay entitlement instead of their original race before the decolonising of British Malaya in the 1950s and '60s. As they settled for a long time and married local people; therefore, they adopted Malay identity. That is why Kingsley Davis did not rely on the official records. He suggested that "the official figures were not complete or uniform" (Davis 1951, 98).

Bengalis also came to British Malaya from outside of Bengal, for instance, Dolly Sinha Davenport came from United Provinces. She recalls that she is a Bengali but her father, a British Government employee, transferred from Eastern Bengal to the United Provinces Municipal Board, as an Electrical Engineer. The original home of her parents was in Dhaka and Comilla. However, Dolly Sinha was educated and brought up in the United Provinces. After her marriage, she came to Singapore in 1966. She further informed that she met a few Bengali families in Singapore who also migrated from the same province (Interview with Mrs Dolly Sinha Davenport on 23 July 2018).

\section{Reinterpretation of historical evidence}

A reinterpretation of historical sources might be an alternate way to show the specific identity and experiences of the Bengali people. The favourable maritime position between the ports of Bengal and Malaya facilitated mobility easier. C. O. Blagden suggested that Chersonesus Aurea (Malay Peninsula) was largely populated by the Siamese, Peguans, Bengalis and fishermen from neighbouring islands, who went there by boats when the Straits were in good weather (Blagden 1927, 9). When the Portuguese launched an expedition (1509) against Malacca, the local Malays considered them as "white Bengalis" or "white-skinned Bengalis" (Leyden (trans.) 1821, 324; Wright 1908, 86; Lloyd and Moore 1986, 28; Hoyt 1993, 30), which denotes that before taking place racial ambiguities in the colonial records, the local Malay people were familiar with the Bengalis well before they were familiar with the Europeans.

Bengali migrations took a new turn with the British expansion over Southeast Asia between the late $18^{\text {th }}$ and early $19^{\text {th }}$ centuries. For example, in 1788 , a census noted that different individuals hailed from Eastern Bengal and Calcutta to George Town and mentioned their occupations as traders, tailors, gunsmiths, woodmen, fishermen, and munshi (religious teachers) (Nasution 2014, 49, 56). Moreover, from 1830 to 1851, Malacca, Penang and Singapore were administered from Calcutta (Annals of Indian Administration 1856 1856, 289).

Thus administrative connectivity created an opportunity for the Bengalis to be mobile in British Malaya. A Bangla-speaking Shaik Ismail bin Abdullah alias Ismail Ballah (c.1843-1928), was born in 
Singapore; his family probably arrived in the 1830s. According to the Political Archive of German Foreign Ministry, Ismail Ballah was mentioned several times in the files of the German Foreign Ministry on the administrative and financial matters of the German consulate in Singapore between 1892 and 1928, especially with regard to the question of the rise in salary for the consulate staff. The source further informed that Ballah had joined the consulate as an office assistant in February 1893. When the German consulate in Singapore did not operate during 1914-1926, he received - through the Swiss consulate - a salary for guarding the consulate archives. His post at the consulate in the year of his death was described as "First Tambi" (Interview with Gerhard Keiper, 13 May 2019; Rashid 2012, 88). Ismail Ballah's great-grandson, Dr Mohamed Tahir, also corroborated the fact of his employment at the German Consulate. Ismail Ballah used to keep records of German imports and exports to and from Singapore. Dr Mohamed Tahir has corroborated that Ismail Ballah used to speak in Bangla (Rashid 2012, 608). Ballah's eldest son, Mohamed Ibrahim bin Shaik Ismail, commonly known as Dr SIM Ibrahim became the President of the Bengal Muslim Association in Singapore in 1938 (Malaya Tribune, 17 March 1938, 18). By the mid of the 1940s, two Bengalis, Muniruddin and M A Majid who came from Eastern Bengal, became leaders of the Association (Interview with Anwarul Haque, son of Muniruddin, on 25 July 2018; Interview with Mushahid Ali, a Bengali descendant, on 19 July 2018; Morning Tribune, 25 July 1946, 11; ST, 1 December 1949, 7). However, when Ismail Ballah died, a newspaper introduced him as an "Arab" (ST, 25 July 1928, 10).

Straits Settlements Government, as well as British officials and merchants, brought their supportive workforces from Bengal to the newly occupied land in the Malay Peninsula. This was possible because the British had already created a class of Baboos in Bengal and brought them to support the clerical jobs in Straits Settlements. During the early $19^{\text {th }}$ century, the British introduced western education, and Persian was replaced by the English language in 1835 . Therefore, the colonial government promoted English education by opening English schools/colleges in Bengal, for instances, Hindu College (1817) and Dacca College (1841). This further led to the creation of an Englisheducated middle class, many of whom found clerical jobs in government administration. This class of people was known as Baboo or Bhadralok (Singh 1985). Baboo Lane on Serangoon Road may have been named after them. Because of the prevalence of the Bengali clerks, the Government recommended that apart from the Malay language the aspirant of government employment in the Straits Settlements should have a fair knowledge of Hindustani, Tamil, Bengali, Chinese and Telugu (ST, 12 November 1859, 2; SFPMA, 8 December 1859, 4).

Bangla is also reported to have been in widely used in Penang (Singapore Chronicle and Commercial Register, hereinafter SCCR, 26 August 1837, 2). Therefore, James Low recommended the recruitment of interpreters of Asian languages, including Bangla. An elderly Bengali clerk, Imami worked as Jemadar. Jemadar is a Persian word denotes the similar to an office assistant, under Sir Benson Maxwell, the Recorder of Penang from 1855 to 1871 . When Maxwell retired, Imami went to Bangkok where he spent rest of his life (Kyshe 1969, 133). A Bengali globetrotter, Ramnath Biswas met some Bengali clerks at the Taiping city in Perak, who were working at the British Resident Office. Some Bengali clerks also worked reputedly in Malacca and settled over there (Biswas 1949, 175; Das 1931, 478).

The demand for the Bangla language in public and academic institutions denotes the existence of a significant number of Bengalis. When fifth Lord Bishop of Calcutta, Daniel Wilson (1778-1858) visited Churches and newly established schools in Malacca in 1834, then the schools managing committee, which consisted of Hon'ble R F. Wingrove Esq., Revd F J Darrah, A. L Johnston, John Connolly, Thos. Oxley, W Napier, T. McMicking, and T. Scott, Esq. to run the schools in Malacca, showed interest to establish a Bengali school alongside an English Female School and other local language schools (SCCR, 30 October 1834, 2). In 1897, St. Anthony's Boys' School (presently St. Anthony's Primary School, Singapore) advertised for the recruitment of teachers with linguistic skills including that of Bangla (Mid-Day Herald and Daily, 23 September 1897). The Kuala Lumpur Courts asked for an interpreter who could read and write Bangla and English (ST, 13 March 1894). 
In 1895, the Selangor Police force also asked for a Bengali interpreter (No.-1957/0054480W National Archives of Malaysia, hereinafter NAM). The demand for Bengali interpreters was extensive during the early $20^{\text {th }}$ century across the Federated Malay States chiefly at Kedah (No.1957/0361064W, 1957/0363247W, 1957/0362649W, 1957/0366225W, 1957/0361151W, 1957/0361860W, NAM).

The recruitment of Bangla-speaking employees at the Singapore Port Office also marks the constant flow of Bengali businessmen and commodities (SCCR, 13 February 1834). The Oriental Bank of Singapore made the first-ever initiative to issue paper currency in four local languages, including Bangla in 1849. The denominations of 5 and 100 dollars were engraved in four languages, e.g., Chinese, Malay, Bangla, and Tamil. It was reported that the notes were more convenient to the mercantile community in many ways over the silver dollar (SFPMA, 10 May 1849, 2; Wright 1908, 244). However, further news regarding the issuing paper currency was not found.

As there was a huge demand for skilled human resources in British Malaya, in particular, engineers and medical practitioners were offered jobs immediately after their arrival in Singapore. Dr K C Sinha reminisced, "As I got down the steps of the ship, the job was waiting there" (Sinha 1983). Dr P R Sengupta reported that two earliest Bengali doctors, namely Paresh Nath Sen (1878-1948) from Dacca and Sarojininath Bardhan (1874-1927) from Comilla arrived in British Malaya in 1907/8 (Sengupta 2013, 40-1, 111-112). Dr Sengupta wrote a biographical book on the Bengali doctors and their contributions in Malaya throughout the $20^{\text {th }}$ century. He showed how the Bengali doctors and their descendants contributed to the public health service and the development of medical education in the Straits Settlements.

The continuity of the Bengalis was also reflected in the formation of a multi-ethnic committee. In 1916, an ethno-racial committee was formed at 1 Jalan Besar in Singapore to support the wounded British army during the WWI. The Hindustani and Bengali people identified themselves separately in that committee. The President, Vice-President, Secretary, and Treasurer were Bengali, and the remaining members introduced themselves as Punjabi and United Provinces (Uttar Pradesh). The leaders of the committee were mostly Bengali including President, K Kader Daud bin Abul Odud, (Bengali); Vice-President, K. C. Sinha, (Bengali); Secretary, Mohammed Ally, (Bengali); Treasurer, Dr. S. N. Bardhan, (Bengali), Syed Gulabshad (Punjabi); Kobad Ally (Bengali); Elahi Bux (United Provinces); Tunda Singh (United Provinces); Hoosen Ally (United Provinces); Ramananda Tewary (United Provinces); Mangal Singh (United Provinces); Mauluvi Singh (United Provinces) (SFPMA, 16 September 1916).

The racial identity began to be clear later, especially at the beginning of the $20^{\text {th }}$ century. For instance, O'Malley informed that in 1911 the number of emigrants from Bengal to Straits Settlements and the Federated Malay States was 3,300 and 3,059 respectively (O'Malley 1913, 174). During the same year, the Federated Malay States and Singapore enumerated the Indians by their race and dialects. Almost 19 Indian languages were found in Straits Settlements including Tamil, Bangla, Hindustani, and Punjabi. Figure 4, 5, and 6 show all Indian languages and its percentage in Singapore, Malacca, and Penang.

By the beginning of the $20^{\text {th }}$ century, a segment of the public in Singapore was concerned about the geographical categorisation, such as "Indian" or "Hindustani" because these generalisations misplaced racial categorisations or classifications. In 1916, the Malaya Tribune recommended that the residents of Singapore and the Civil servants should consider the customs and cultures of different races in the cosmopolitan space (Malaya Tribune, hereinafter MT, 27 June 1916, 8). Due to the public consciousness, census administrators instructed the enumerators to ask birthplace and ethnic identity during the census of 1921. By doing this, the Malay enumerators could easily notify if any person of United Provinces, or a Sikh or a Punjabi described himself as a "Bengali" (Vlieland 1932), 83, 84). The people also became aware of the clarification of racial identification in the 1930s. For instance, some interviewees of different ethnicities including Malayalee, Telugu, Tamil and Sikh recalled that the Bengali and Punjabi came from Bengal and Punjab accordingly. The interviewees sharply distinguished ethnicities in their oral testimonies and suggested that the Punjabi and Sikh should not be mixed up with the Bengali (Menon 1985; Palanivelu 1985; Rajan 1987; Singh 1984; 
Singh 1985). That is why the Singapore Encyclopedia illustrated that the term "Bengali" was in use in Singapore since the 1950s (Koh et al. 2006, 248).

\section{Indian Languages in Singapore (1911)}

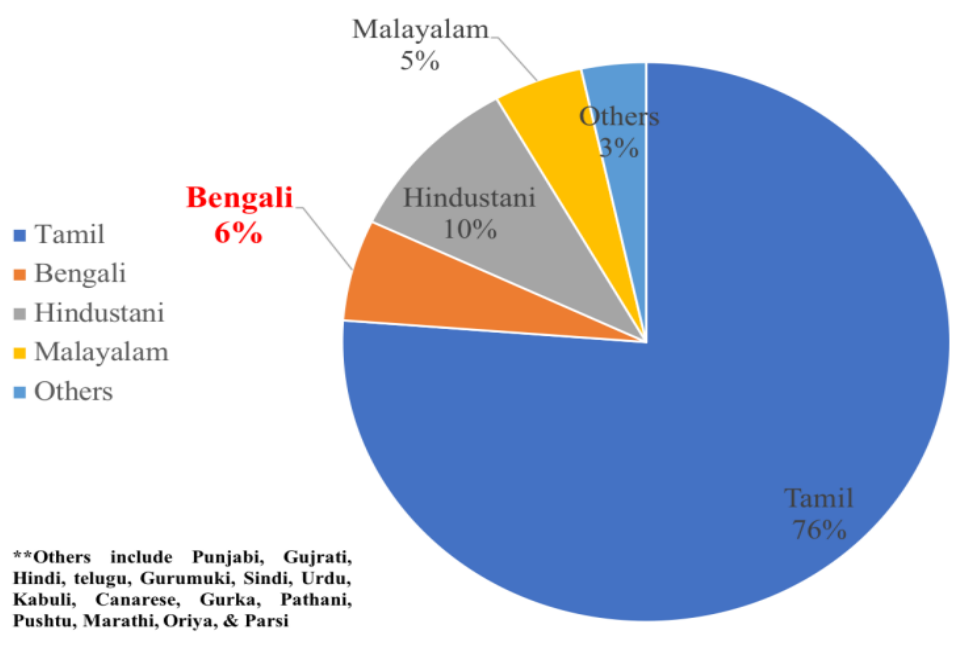

Figure 4. Percentage of Indian languages in Singapore Source: Marriott 1911, 66-8.

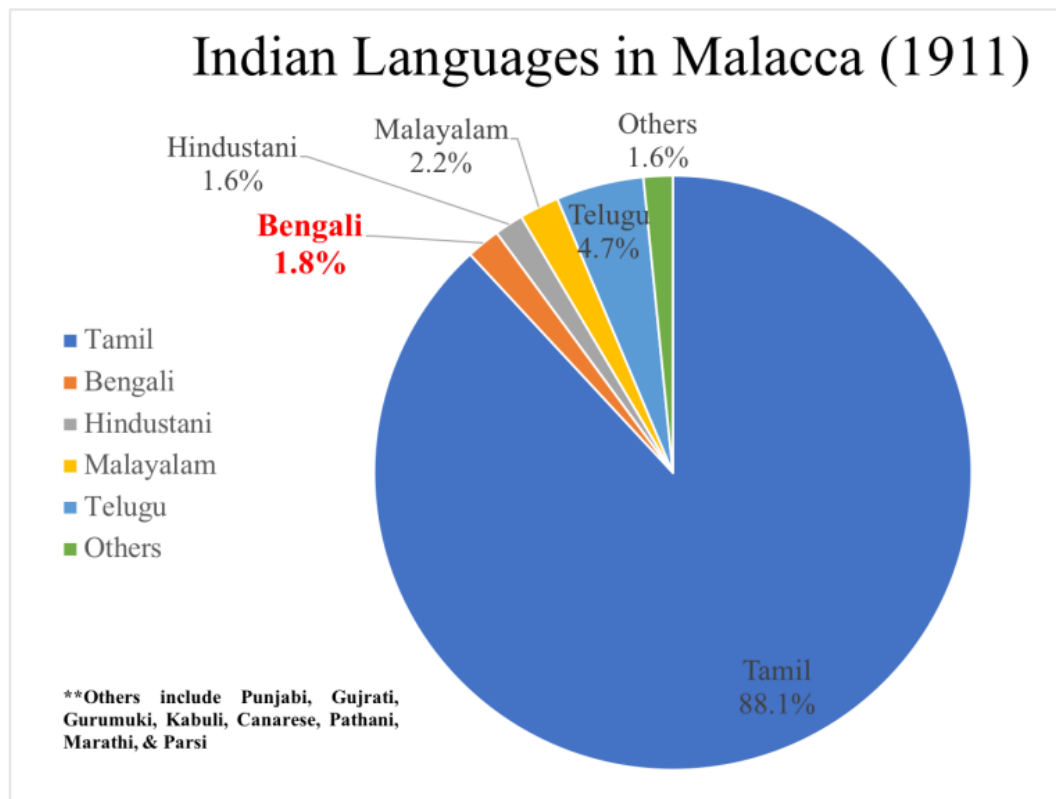

Figure 5. Percentage of Indian languages in Malacca Source: Marriott 1911, 66-8. 


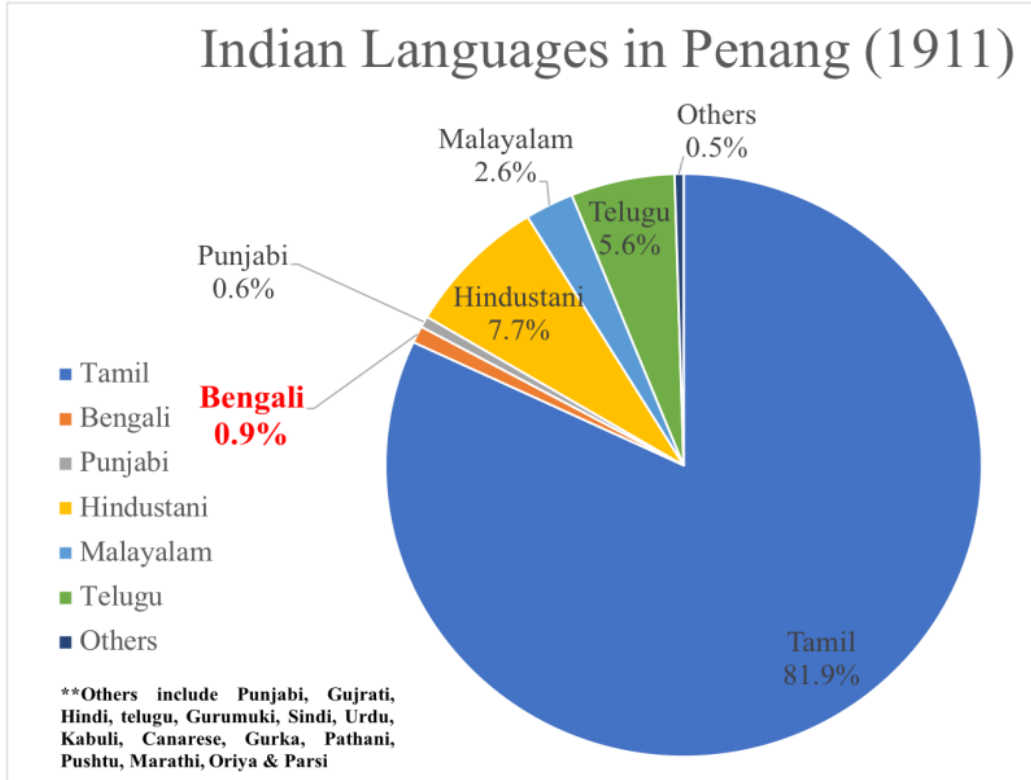

Figure 6. Percentage of Indian languages in Penang Source: Marriott 1911, 66-8.

The above discussions suggest that despite the categorical and terminological ambiguities, primary as well as secondary sources point to the fact that a considerable number of Bengalis were active in British Malaya.

\section{Post-colonial epoch: a new wave of Bengali migration}

In 1947, Bengal was partitioned along the communal line; when Hindu majority West Bengal became part of India, and Muslim majority Eastern Bengal became part of Pakistan. Since then the people of East Bengal were identified as either East Pakistani or Pakistani. The Bengalis from West Bengal came to be known as Indian. In 1957, Smith estimated that the number of Indians (including Pakistanis) was 696,000 and 124,000 in the Federation of Malaya and Singapore respectively (Smith 2001, 263). Sandhu suggested that all nationals of Pakistan were Punjabi and Bengali Muslims (Sandhu 1961). The people who migrated from post-independence Bangladesh, particularly in the 1980s identified themselves as Bangladeshi. However, the people of West Bengal retained their identity as Bengali. Bangladeshi identity appeared when President of the People's Republic of Bangladesh Ziaur Rahman assumed power and introduced "Bangladeshi nationalism". A different wave of Bangladeshi migrants took place in Malaya during the 1980s and 1990s for a few reasons (Khondker 2008, 183-84). Firstly, the massive construction and development work in Singapore, Malaysia, and Brunei. Secondly, the fortune of the Bangladeshi migrant declined in the Middle East, because of the Persian Gulf War (1990-1991). Thirdly, Bangladeshi professional classes, including teachers, doctors, and engineers, also migrated in search of better opportunity. Some of them settled, married local women and started their own business. A member of the Bengali community informed that in the early $21^{\text {st }}$ century that there were about 1,000 Bengali families in Singapore, in addition to the 1.5 lakh Bangladeshis (Telegraph, 21 July, 2013).

\section{Conclusion}

In conclusion, this article has illustrated two different issues. Firstly, as a burgeoning area in the historical studies, the reconstruction of transnational history might be problematic if historians failed to notice the limitations in colonial records. Initially, British colonial census takers were not aware of ethnic-racial classifications; instead, they systematically quantified the population in their colonies, particularly, in Malaya. Therefore, this study suggests that transnational historians will consider the stringent systems of enumeration or ambiguities in the colonial records. The second set of issues is 
that locating the Bengali transnational community who were bundled together under the generic term of "Indian," "Hindustani," or "Punjabi." The above discussions have shown that during the British colonial period, diverse South Asian migrants were enumerated under different umbrella terms, including "Indians" in Malaya, because they were migrated from the British Indian territory. Therefore, the reconstruction of the history of South Asian transnational communities, in particular, the Bengalis in Malaya, has two specific problems. On the one hand, they were designed under umbrella terms, and the non-Bengalis from different parts of India were blended with them, on the other hand. In this context, this study has provided some alternate ways of dealing with such ambiguities, which will enrich understanding the colonial records for reconstructing the history of a transnational community. Firstly, the researcher has demonstrated an indirect mode of estimation of Bengali migrants through the census readings, such as the statistics of birthplace. During the enumeration in the Straits Settlements, the census takers showed that some Bengalis were born in Bengal but enumerated in the British Malaya; and the Bengal Government also indicated the same as the Straits Settlements that some Bengali were born in Malaya. These indirect evidence show the Bengali mobility in Malaya. Moreover, many of Bangla-speaking Muslim migrants married to local people and assumed Malay identity. Secondly, the researcher has located the Bengali mobility through the reinterpretation of historical evidence. The local Malay people were familiar with the Bengalis well before they were familiar with the Europeans. Besides, administrative connectivity combined with maritime highways assisted the Bengali mobility towards the Malaya. Thus, this article explicitly demonstrates that, with the British colonialism, a considerable number of Bengali migrated to Malaya. They were involved in various professions, including administrative staff, engineers, medical practitioners as well as manual labourers. Therefore, this study will further contribute to the existing literature on Bengali migration in Malaya, and broadly to the Asian migration studies. This paper suggests that by the turn of the $20^{\text {th }}$ century, the Bengali migrants created a civil society and diasporic space, and their presence in the Malay Peninsula in the postcolonial times was built during the colonial epoch that needs to be considered.

\section{Acknowledgement}

This article is written in the light of a conference paper which was presented at the $12^{\text {th }}$ Singapore Graduate Forum on Southeast Asian Studies, 26-28 July 2017, Singapore. I acknowledge the support received from the Asia Research Institute for granting a travel fund to attend the conference. Thanks to the anonymous scholars who made insightful comments during the session as well as the personal conversations, in particular, with Professors Sunil Amrith of Harvard University, Bruce M Lockhart of National University of Singapore, and Iftekhar Iqbal of Universiti Brunei Darussalam.

\section{References}

1957/0054480W, Application from Mr. Gheewala, Bengali Interpreter of Courts for the post of Munshi to Selangor Police Force, $17^{\text {th }}$ January 1895.

1957/0361064W, Request that a Bangalee [Bengali] Interpreter be appointed at Sungai Petani Court, $1^{\text {st }}$ February 1915 .

1957/0361151W, Requests to know whether he can enrol two Bengali watchmen as special constables at Sungai Batu Estate, $31^{\text {st }}$ January 1915.

1957/0361860W, Asks that A.C.P. (Assistant Corporal Police) be instructed to supply police Bengali Interpreter when required by the Courts, $28^{\text {th }}$ April 1915.

1957/0362649W, Applies for the Post of Bengali Interpreter, 20 ${ }^{\text {th }}$ September 1915.

1957/0363247W, Applies for the Post of Bengali Interpreter, $25^{\text {th }}$ November 1915.

$1957 / 0366225 \mathrm{~W}$, Asks for a transfer of $\$ 57.13$ from the vote "salary of Bengali Interpreter" to the vote "salary and duty allowance of the legal adviser", $15^{\text {th }}$ August 1916. 
Aiyar, K A Neelakandha. 1938. Indian Problems in Malaya: A Brief Survey in Relation to Emigration. Kuala Lumpur: The India Office.

Akyeampon, Emmanuel. 2013. "Slavery, Indentured Labor, and the Making of a Transnational World" in A Companion to Diaspora and Transnationalism edited by Ato Quayson and Girish Daswani, 163-171. West Sussex: Blackwell Publishing Ltd.

Allen, Margaret. 2005. "Innocents Abroad" and "Prohibited Immigrants": Australians in India and Indians in Australia 1890-1910" in Connected Worlds: History in Transnational Perspective Canberra, eds. Ann Curthoys and Marilyn Lake, 111-124, Canberra: ANU E-Press.

Ampalavanar, Rajeswary. 1981. The Indian Minority and Political Change in Malaya 1945-1957. Kuala Lumpur, Oxford, New York, and Melbourne: Oxford University Press.

Amrith, Sunil S. 2011. Migration and Diaspora in Modern Asia. London: Cambridge University Press.

Amrith, Sunil S. 2013. Crossing the Bay of Bengal: The Furies of Nature and the Fortunes of Migrants. London: Harvard University Press.

Anderson, Benedict. 2006. Imagined Communities: Reflections on the Origin and Spread of Nationalism. London: Verso.

Annals of Indian Administration 1856. 1856. Serampore: Marshall D'cruz.

Appadurai, Arjun. 1990. "Disjuncture and Difference in the Global Cultural Economy", Theory, Culture \& Society 7: 295-310.

Arasaratnam, Sinnappah. 1970. Indians in Malaysia and Singapore. London, Kuala Lumpur: Oxford University Press.

Basch, Linda., Schiller, Nina Glick., \& Blanc, Cristina Szanton. 2005. Nations Unbound: Transnational Projects, Postcolonial Predicaments, and Deterritorialized Nation States. London, New York: Rutledge.

Bayly, C. A., Beckert, Sven., Connelly, Matthew., Hofmeyr, Isabel., Kozol, Wendy., and Seed, Patricia. 2006. "AHR Conversation: On Transnational History". The American Historical Review 111 (5): 1441-1464.

Belle, Carl Vadivella. 2015. Tragic Orphans: Indians in Malaysia. Singapore: ISEAS.

Bergantz, Alexis. 2015. "French Connection: The culture and politics of Frenchness in Australia, 1890-1914". PhD Dissertation, Australia: Australian National University.

Biswas, Ramnath. 1949. Malaysia Vromon, [Travel to Malaysia]. Calcutta: Prokasok Sattonarayan Bhattacharjo.

Blagden, C. O. 1927. Introduction and notes to "Report of Governor Balthasar Bort on Malacca 1678." Translated by M. J. Bremner, Journal of the Malayan Branch of the Royal Asiatic Society V. Part -I, 1-9.

Bourne, Randolph. 1916. “Trans-National America”. Atlantic Monthly 118: 86-97.

Braddell, Roland. 1934. The lights of Singapore. London: Methuen.

Census of the British Empire 1901. 1906. London: Darling \& Sons.

Chakrabarty, Dipesh. 1992. "Postcoloniality and the Artifice of History: Who Speaks for "Indian" Pasts?," Representations, no. 37, Special Issue: Imperial Fantasies and Postcolonial Histories (Winter): 1-26.

Chakrabarty, Dipesh. 2000. Provincializing Europe: postcolonial thought and historical difference. Princeton: Princeton University Press.

Chanderbali, David. 2008. Indian Indenture in British Malaya: Policy and practice in the Straits Settlements. United Kingdom: Peepal Tree Press.

Clifford, Hugh. 1904. Further India: Burma, Malaya, Siam, and Indo-China. London: Lawrence and Bullen Ltd. 
Das, Ganendra Mohun. 1931. Banger Bahire Bangali, (Bengalis Outside Bengal) part III. Calcutta: Indian Publishing House.

Davis, Kingsley. 1951. The Population of India and Pakistan. Princeton: Princeton University Press. Fuccaro, Nelida. 2005. "Mapping the transnational community: Persians and the space of the city in Bahrain, c.1869-1937" in Transnational Connections and the Arab Gulf edited by Madawi AlRasheed, 39-58, Routledge.

Gait, E. A. 1913. Census of India 1911, Vol-1, India, part-II, Tables. Calcutta: Superintendent Government Printing.

Hirschman, Charles. 1986. "The Making of Race in Colonial Malaya: Political Economy and Racial Ideology" Sociological Forum 1, no. 2: 330-362.

Hirschman, Charles. 1987. "The Meaning and Measurement of Ethnicity in Malaysia: An Analysis of Census Classifications". The Journal of Asian Studies 46, no. 3: 552-582.

Ho, Engseng. 2006. The Graves of Tarim: Genealogy and Mobility across the Indian Ocean. California: University of California Press.

Hoyt, Sarnia Hayes. 1993. Old Malacca. Kuala Lumpur: Oxford University Press.

Iriye, Akira and Saunie, Pierre-Yves. ed. 2009. The Palgrave Dictionary of Transnational History: From the mid-19 $9^{\text {th }}$ century to the present day. UK: Palgrave Macmillan.

Iriye, Akira. 2013. Global and Transnational History: The Past, Present, and Future. Basingstoke: Palgrave Macmillan.

Jackson, Isabella. 2012. "The Raj on Nanjing Road: Sikh Policemen in Treaty-Port Shanghai", Modern Asian Studies 46, no. 6: 1672-1704.

Kaur, Amarjit. 2011. "Indian Ocean Crossings: Indian Labor Migration and Settlement in Southeast Asia, 1870 to 1940" in Connecting Seas and Connected Ocean Rims: Indian, Atlantic, and Pacific Oceans and China Seas Migrations from the 1830s to the 1930s edited by Donna R. Gabaccia and Dirk Hoerder, 134-166, Leiden and Boston: Brill.

Kaur, Arunajeet. 2009. Sikhs in the policing of British Malaya and Straits Settlements (1874-1957). Saarbrücken: VDM Verlag Dr. Müller.

Khondker, Habibul Haque. 2008. "Bengali-Speaking Families in Singapore: Home, Nation and the World”, International Migration 46, no. 4: 178-198.

Knight, W Andy. 2002. "Conceptualizing Transnational Community Formation: Migrants, Sojourners and Diasporas in a Globalized Era”, Special Issue on Migration and Globalization, Canadian Studies in Population 29, no. 1: 1-30.

Koh, Tommy Thong Bee., Auger, Timothy., Yap, Jimmy., Chian Ng, Wei. eds. 2006. Singapore: The Encyclopedia. Didier Millet, Singapore.

Kyshe, J W Norton. 1969. "A Judicial History of the Straits Settlements 1786-1890”, Malaya Law Review, Special Issue to Commemorate: The One Hundred and Fiftieth Anniversary of Singapore 11, no. 1: 38-179.

Leyden, John (trans.). 1821. Malay Annals, with an introduction by Sir Thomas Stamford Raffles. London: Longman, Hust, Rees, Orme, and Brown.

Lloyd, Ian and Moore, Wendy. 1986. Malacca, Singapore: Time Edition.

Lwin, Thet. 2008. "Indians in Myanmar" in Rising India and Indian Communities in East Asia edited by K Kesavapany, A Mani, and P Ramasamy. 485-497, Singapore: ISEAS.

Malaya Tribune, Singapore, 1914.

Markovits, Claude., Pouchepadass, Jacques., and Subrahmanyam, Sanjay. eds. 2003. Society and Circulation: Mobile People and Itinerant Cultures in South Asia, 1750-1950. Delhi: Permanent Black. 
Marriott, H. 1911. Report on the Census of the Straits Settlements, taken on the 10 March, 1911. Singapore: Government Print Office.

McCann, Gerard. 2011. "Sikhs and the City: Sikh history and diasporic practice in Singapore". Modern Asian Studies 45 (6): 1465-1498.

Metcalf, Thomas R. 2007. Imperial Connections: India in the Indian Ocean arena, 1860-1920. Berkeley, Los Angeles \& London: University of California Press.

Mid-Day Herald and Daily, Singapore, 1894.

Morning Tribune, 25 July 1946

Nasution, Khoo Salma. 2014. The Chulia in Penang: Patronage and Place-Making around the Kapitan Kling Mosque 1786-1957. Penang: Areca Books.

O’Malley, L.S.S. 1913. Census of India, 1911, Vol. V, Bengal, Bihar and Orissa and Sikkim, Part 1: Report. Calcutta: Bengal Secretariat Book Depot.

Onley, James. 2005. "Transnational merchants in the nineteenth-century Gulf: the case of the Safar family" in Transnational Connections and the Arab Gulf edited by Madawi Al-Rasheed, 59-90, London and New York: Routledge.

Onley, James. 2007. "Transnational merchant families in the nineteenth- and twentieth-century Gulf" in The Gulf Family: Kinship Policies and Modernity, edited by London Middle East Institute and Gulf Cooperation Council, 37-56, London: Saqi in association with London Middle East Institute, SOAS.

Pirbhai, Mariam. 2003. "The Multiple Voices of Indenture History: The South Asian Diasporic Novel in English". PhD dissertation, Universite de Montreal.

Rahman, Md Mizanur. 2017. Bangladeshi Migration to Singapore: A Process-Oriented Approach. Singapore: Springer.

Rashid, Faridah Abdul. 2012. Biography of the Early Malay Doctors 1900-1957 Malaya and Singapore. Xlibris Corporation.

Risley, H. H. \& E. A. Gait. 1903. Census of India, 1901, Vol.-I, India, Part-I, Report. Calcutta: Office of the Superintend of Government Printing.

Sadka, Emily. 1968. The Protected Malay States 1874-1895. Kuala Lumpur: University of Malaya Press.

Sandhu, K. S. 1961. "Indian migration and population change in Malaya, c.100-1957 AD: a Historical Geography”. MA Thesis, University of British Columbia.

Sengupta, P. R. 2013. Malaysia \& Bengali Doctors 1907-2012: A personal perspective. Bloomington: Xlibris.

Singapore Chronicle and Commercial Register, Singapore, 1824.

Singapore Free Press and Mercantile Advertiser, Singapore, 1835.

Smith, T. E. 2001. "Immigration and permanent settlement of Chinese and Indians in Malaya: and the future growth of the Malay and Chinese communities" in South East Asia: Colonial History, vol. III, High Imperialism (1890s-1930s) edited by Paul H. Kratoska, 255 -267. London and New York: Routledge.

Straits Times, Singapore, 1845.

Sultana, Nayeem. 2008. "The Bangladeshi Diaspora in Malaysia: Organizational Structure, Survival Strategies and Networks.” PhD diss., ZEF, Centre for Development Research, University of Bonn,

Telegraph, 21 July, 2013.

Tinker, Hugh. 1974. A New System of Slavery: The Export of Indian Labour Overseas, 1830-1920. London: Oxford University Press.

Turnbull, C. M. 1989. A History of Singapore 1819-1988. Singapore, Oxford, and New York: Oxford University Press.

Ullah, AKM Ahsan. 2007. "Rationalizing migration: Bangladeshi migrant workers in Hong Kong and Malaysia." PhD diss., City University of Hong Kong. 
Ullah, AKMA. 2010. Rationalizing Migration Decisions: Labour Migrants in East and Southeast Asia. London: Ashgate.

Vlieland. C. A. British Malaya [the colony of the Straits Settlements and the Malay states under British protection, namely the federated states of Perak, Selangor, Negri Sembilan and Pahang and the states of Johore, Kedah, Kelantan, Trengganu, Perlis and Brunei: A report on the 1931 census and on certain problems of vital statistics]. London: Crown Agents for the Colonies, 1932.

Winstedt, Richard. 1951. Malaya and Its History. London: Hutchinson House.

Wright, Arnold (ed.). 1908. Twentieth Century Impressions of British Malaya: Its History, People, commerce, Industries, and Resources. London: Lloyd's Greater Britain Publishing Company Ltd.

\section{Interviews}

Email Corresponding Email of Gerhard Keiper, Political Archive of the Federal Foreign Office, Berlin. 13 May 2019. Subject: “Anfrage zu ehemaligem Konsulatspersonal Singapur”.

Sinha, Hena. 21 Oct 1983, Acc. No. 000354. National Archives of Singapore.

Singh, Seva. 11 Apr 1984, Acc. No. 000418. National Archives of Singapore.

Menon, Sukumara Ittamuittil. 9 May 1985, Acc. No. 000557. National Archives of Singapore.

Singh, Mohinder. 24 Jun 1985, Acc. No. 000546. National Archives of Singapore.

Palanivelu, Natesan. 10 Oct 1985, Acc. No. 000588. National Archives of Singapore.

Rajan, Soundara. 25 Nov 1987, Acc. No. 000845. National Archives of Singapore.

Ali, Mushahid, 19 July 2018, Far East Plaza, Singapore. Interview by Gazi Mizanur Rahman.

Davenport, Dolly Sinha. 23 July 2018, at her house, Singapore. Interview by Gazi Mizanur Rahman. Haque, Anwarul. 25 July 2018, Guild House, National University of Singapore, Singapore. Interview by Gazi Mizanur Rahman. 